\title{
Intramandibular Route of Administration
}

National Cancer Institute

\section{Source}

National Cancer Institute. Intramandibular Route of Administration. NCI Thesaurus. Code C156590.

Administration within the mandible. 